\title{
Article \\ Study on Double-Layer Ignition Sintering Process Based on Autocatalytic Denitrification of Sintering Layer
}

\author{
Benjing Shi ${ }^{1,+} \mathbb{D}$, Junying Wan ${ }^{2,3, *},+$, Tiejun Chen ${ }^{2,3, *}$, Xianlin Zhou ${ }^{2,3, * \mathbb{D}}$, Yanhong Luo ${ }^{2,3}$, Jiawen Liu ${ }^{2,3}$, \\ Mengjie $\mathrm{Hu}^{2,3}$ and Zhaocai Wang ${ }^{1}$
}

1 Zhongye Changtian International Engineering Co., Ltd., Changsha 410205, China; shi_benjing@126.com (B.S.); midrex@163.com (Z.W.)

2 School of Resources and Environmental Engineering, Wuhan University of Science and Technology, Wuhan 430081, China; yhluo@wust.edu.cn (Y.L.); liujiawen0224@163.com (J.L.); 15871452760@163.com (M.H.)

3 Hubei Key Laboratory for Efficient Utilization and Agglomeration of Metallurgic Mineral Resources, Wuhan 430081, China

* Correspondence: jywan92@163.com (J.W.); chentiejun@wust.edu.cn (T.C.); xlzhou@wust.edu.cn; (X.Z.)

+ These authors contributed to the work equally and should be regarded as co-first authors.

\section{check for}

updates

Citation: Shi, B.; Wan, J.; Chen, T.; Zhou, X.; Luo, Y.; Liu, J.; Hu, M.; Wang, Z. Study on Double-Layer Ignition Sintering Process Based on Autocatalytic Denitrification of Sintering Layer. Minerals 2022, 12, 33. https://doi.org/10.3390/min12010033

Academic Editors: Rajesh Kumar Jyothi, Rafael Santos,

Shivakumar Angadi

and Sanjay Agarwal

Received: 22 November 2021

Accepted: 21 December 2021

Published: 25 December 2021

Publisher's Note: MDPI stays neutral with regard to jurisdictional claims in published maps and institutional affiliations.

Copyright: (C) 2021 by the authors. Licensee MDPI, Basel, Switzerland. This article is an open access article distributed under the terms and conditions of the Creative Commons Attribution (CC BY) license (https:// creativecommons.org/licenses/by/ $4.0 /)$.
Abstract: An efficient sintering process was proposed based on the autocatalytic denitrification of the sintered ore. The catalytic denitrification of sintered ore, the effect of double-layer ignition sintering process on the emission reduction in nitrogen oxides, and the impact on the quality of sintered ore were studied. The results showed that the catalyzed reduction of NO with sinter ore as a catalyst has a significant effect; when the airspeed reaches $3000 \mathrm{~h}^{-1}$, the temperature is $500{ }^{\circ} \mathrm{C}$, and the conversion rate of $\mathrm{NO}$ can reach $99.58 \%$. The sinter yield of double-layer ignition sintering is increased, solid fuel consumption is slightly reduced, falling strength is slightly increased, and drum strength is slightly decreased. Under the conditions of layer height proportion of $320 / 400 \mathrm{~mm}$ (lower/upper) and ignition time interval of $10 \mathrm{~min}$, the yield, drum strength, shatter strength, and solid fuel consumption reached $61.60 \%, 54.82 \%, 46.75 \%$, and $69.55 \%$, respectively. $\mathrm{NO}_{\mathrm{x}}$ concentration under the $16 \%$ baseline oxygen content $\left(c_{\left(\mathrm{NO}_{x)}^{\prime}\right.}\right)$ in the flue gas of double-layer ignition sintering is reduced to a certain extent, and the generation time of $\mathrm{NO}_{\mathrm{x}}$ is greatly shortened. The double-layer ignition sintering process can reduce the emission of nitrogen oxides in the sintering process under the condition of guaranteeing the quality of sinter, which has great economic and environmental benefits.

Keywords: nitrogen oxide; sintering; catalytic reduction; double-layer ignition; denitration

\section{Introduction}

Nitrogen oxide $\left(\mathrm{NO}_{\mathrm{x}}\right)$ is a major air pollutant [1]. The excess emission of $\mathrm{NO}_{\mathrm{x}}$ has brought harm and trouble to human beings repeatedly due to its role in the formation of photochemical smog and acid rain [2,3]. The iron and steel industry is one of the major polluters in the industrial field; the $\mathrm{NO}_{\mathrm{x}}$ emissions from iron and steel industry approximately account for $6 \%$ of the total industrial emissions in China [4,5]. Meanwhile, sintering, as one of the most polluting processes in steel production, accounts for about $50 \%$ of the total $\mathrm{NO}_{\mathrm{x}}$ emissions of iron and steel production [6,7]. According to the formation mechanism, $\mathrm{NO}_{\mathrm{x}}$ can be divided into three types: thermal $\mathrm{NO}_{\mathrm{x}}$, prompt $\mathrm{NO}_{\mathrm{x}}$, and coal $\mathrm{NO}_{\mathrm{x}}[8,9]$. In the sintering process, $\mathrm{NO}_{\mathrm{x}}$ mainly comes from coal combustion, accounting for about $80 \%-90 \%$ of the total $\mathrm{NO}_{\mathrm{x}}$ emissions from the sintering machine [10]. In the process of $\mathrm{NO}_{x}$ production by coal combustion, $\mathrm{NO}$ accounts for about $95 \%, \mathrm{NO}_{2}$ only accounts for about 5\%, and $\mathrm{N}_{2} \mathrm{O}$ is very small [11]. In 2019, the Ministry of Ecology and Environment of the People's Republic of China implemented "Opinions on promoting the implementation of ultra-low emissions in the steel industry", which point out that the steel industry has begun to implement ultra-low emission policies, especially the average hourly $\mathrm{NO}_{x}$ emission concentration in sintering machine flue gas, which is strictly controlled to $50 \mathrm{mg} / \mathrm{m}^{3}$, which has brought tremendous environmental pressure to iron and steel 
enterprises. Therefore, the comprehensive treatment of $\mathrm{NO}_{\mathrm{x}}$ in sintering process has become the top priority of environmental protection standards for iron and steel enterprises.

Recent and ongoing efforts aim at further reducing ambient $\mathrm{NO}_{\mathrm{x}}$ concentration globally, which mainly includes source control, process control, and end-of-pipe treatment technology. At present, resource control mainly includes the use of low-nitrogen coke powder and biomass carbon to replace high nitrogen fuel [12], the use of new low-nitrogen burners, etc. In terms of process control, it mainly includes adjusting sintering process parameters, using sintering additives [2,13], fuel pretreatment [14], gas/steam injection [15], flue gas circulation [16], etc. The main processes of the end-of-pipe treatment technology include selective non-catalytic reduction (SNCR) [17-19], selective catalytic reduction (SCR) [20-22], activated carbon adsorption [23], and oxidative absorption [24]. The $\mathrm{NO}_{\mathrm{x}}$ concentration in sintering flue gas can be reduced to below $50 \mathrm{mg} / \mathrm{m}^{3}$ by the end-of-pipe treatment technology, but there are many problems such as high investment in denitrification equipment, easy deactivation of catalyst, and high denitrification operation cost [10]. Therefore, the treatment of sintering flue gas should be transformed from relying on a single terminal treatment technology to process control coordinated the end-of-pipe treatment technology.

Flue gas recirculation technology is proposed by researchers aiming to reducing the exhaust gas emission and reusing waste heat in 20th century, which is developed based on a principle that parts of waste gases recycled into sintering bed $[4,25]$. Flue gas recirculation (FGR) is a method reported to effectively reduce $\mathrm{NO}_{x}$ pollutant emissions by recirculating part of the flue gas [26-29], such as the emission-optimized sintering process-EOS [30]. Linz steelworks and Siemens VAI have developed an improved denitrification process with recycling flue gas-eposint [31]. In the sinter zone, $\mathrm{NO}-\mathrm{CO}$ catalytic reduction occurs in the range of $500-900{ }^{\circ} \mathrm{C}$. When the sinter temperature is $700{ }^{\circ} \mathrm{C}$, the highest nitrogen reduction ratio (NRR) achieved is $8 \%$; $\mathrm{NO}_{\mathrm{x}}$ in flue gas is mainly a product of fuel combustion in the combustion zone, as the nitrogen conversion rate reaches $50 \%-60 \%$, because $\mathrm{N}$-containing intermediates exist during the fuel combustion. The NRR in the combustion zone reaches a range of $18 \%-20 \%$ [16,32]. If sinter can be used as denitrification catalyst, it can be used in a large number of production applications. In the sintering system, the calcium ferrite reaction generated in the sintering process plays a catalytic role in the reduction reaction of $\mathrm{NO}_{x}$ generated in the same system [33], but the paper only discusses the catalytic reduction of $\mathrm{NO}_{\mathrm{x}}$ in the calcium ferrite system, and it is difficult to realize the preparation and application of calcium ferrite in the actual production process. Sinter is the target product of the sintering process.

The double-layer ignition sintering method [34] makes full use of the lower sinter, itself containing a reduction in the catalyst composition, using less high-temperature sintering ore in the sintering process, as denitration catalysts, effective in the sintering process of $\mathrm{NO}_{\mathrm{x}}$ catalytic reduction, environmental protection, and synchronous sintering and denitration online, ensure the efficiency of sintering and the demand of the catalyst and greatly reduce the sintering process of denitration operation costs.

This research aims to use sintered ore as a denitrification catalyst to study the effect of sintered ore on the reduction of nitrogen oxides and to explore the autocatalytic denitrification based on the sinter bed. Meanwhile, the effect of double-layer ignition sintering process on the emission reduction of nitrogen oxides and the impact on the quality of sintered ore was studied; research results can be used to control the sintering nitrogen oxide process to reduce the production and emission of nitrogen oxides, which has very important environmental protection significance and economic prospects.

\section{Experiment}

2.1. Experimental Materials

2.1.1. Raw Materials for Catalytic Reduction

In this experiment, sintered ore obtained from a steel plant was used as denitrification catalyst. The main chemical compositions of sintered ores tested by ICP-AES are shown in Table 1 . The results showed that the total iron content and FeO content are $56.89 \%$ and 
$7.32 \%$, respectively. The binary basicity, defined as the ratio of $\mathrm{CaO}$ and $\mathrm{SiO}_{2}$ mass content in the sintered ores, was 1.98 .

Table 1. Chemical composition of catalyst/wt\%.

\begin{tabular}{cccccc}
\hline TFe & $\mathbf{F e O}$ & $\mathbf{C a O}$ & $\mathbf{M g O}$ & $\mathbf{A l}_{\mathbf{2}} \mathbf{O}_{\mathbf{3}}$ & $\mathrm{SiO}_{\mathbf{2}}$ \\
\hline 56.89 & 7.32 & 10.87 & 1.9 & 1.91 & 5.48 \\
\hline
\end{tabular}

The phase composition of sintered ore tested by an X-ray diffractometer (XRD, D/Max2500, Rigaku Co., Tokyo, Japan) was shown in Figure 1. The results showed that ironbearing minerals in sintered ore are mainly calcium ferrite, hematite, magnetite, and hedenbergite. Diffraction peaks at 11.9, 27.6, 34.3, 41.5, and 60.7 reveal the presence of calcium ferrite [35,36]. Diffraction peaks at 33.2, 35.6, 41.0, 49.5, 54.1, 62.5, 64.1, and 72.0 of the sintered ore are observed, which reveal the presence of hematite [37]. Diffraction peaks at $30.1,35.4,43.1,53.4,56.9,62.6,73.9$, and 75.0 of the sintered ore are observed, which can be attributed to the characteristic peaks of $\mathrm{Fe}_{3} \mathrm{O}_{4}$ [38]. Diffraction peaks at 29.5, 29.7, 35.0, and 35.3 of the sintered ore are observed, which reveal the presence of hedenbergite, which refer to JCPDS (Joint Committee on Powder Diffraction Standards) (01-071-1500).

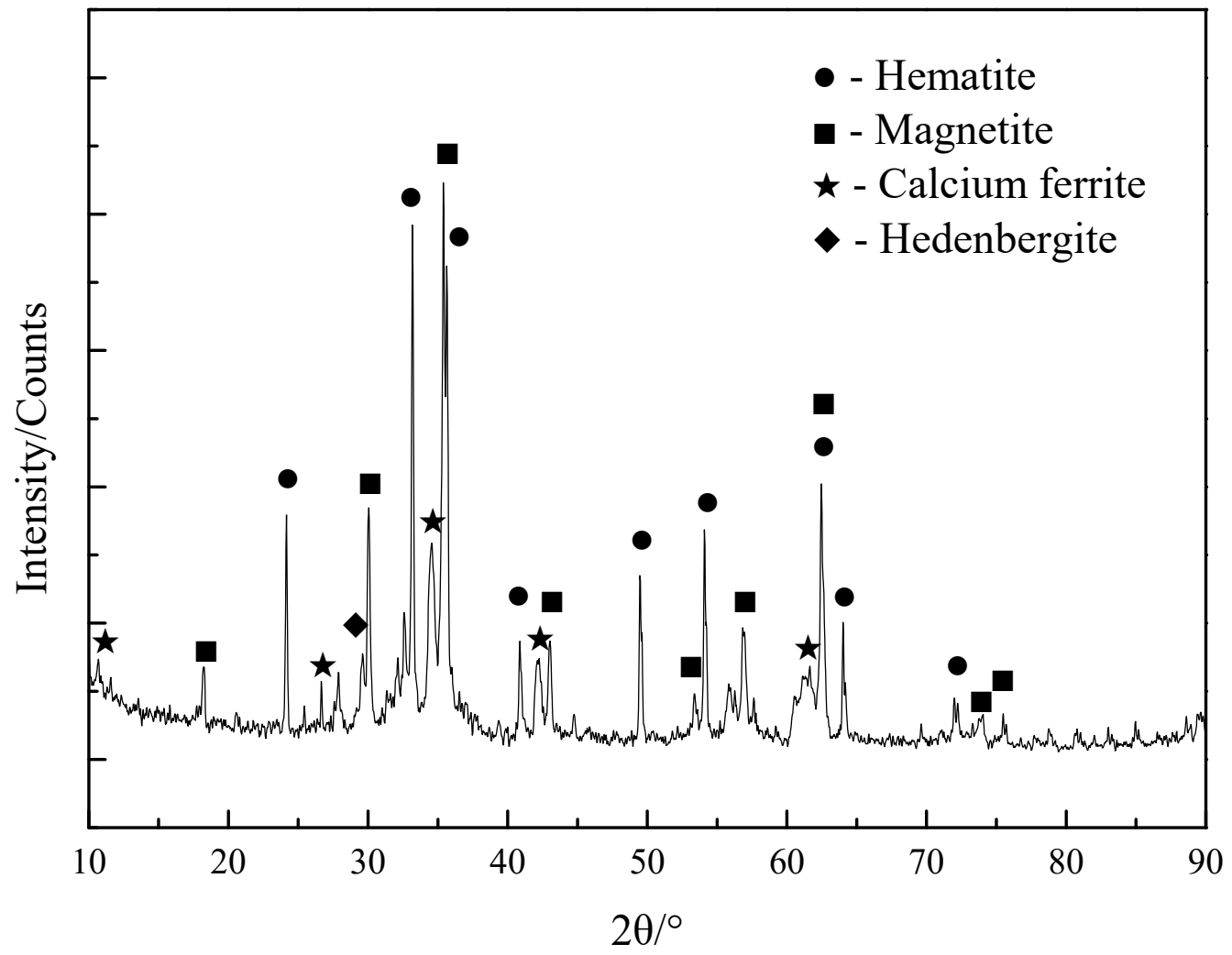

Figure 1. XRD analysis of catalyst.

\subsubsection{Raw Materials for Double-Layer Ignition Sintering}

The raw materials used in the sintering experiment in this study were obtained from a sintering plant of iron and Steel Group Co., LTD. (Wuhan, China). The main chemical compositions of iron ore fines, return fines, fuel, and fluxes (including calcined lime, limestone and dolomite) tested by ICP-AES are shown in Table 2. The iron grade of iron ore fines is $61.47 \%$, and the burning loss is $5.14 \%$. The grade of return fines is $54.66 \%$, and the burning loss is $1.21 \%$. The fuel is anthracite, and its industrial analysis is shown in Table 3 . The fixed carbon mass fraction is $79.86 \%$, and ash and volatile matter are $15.06 \%$ and $3.63 \%$, respectively. 
Table 2. Chemical composition of raw materials/wt $\%$.

\begin{tabular}{cccccccccc}
\hline Raw Materials & $\mathbf{T F e}$ & $\mathbf{F e O}$ & $\mathbf{S i O}_{\mathbf{2}}$ & $\mathbf{C a O}$ & $\mathbf{A l}_{\mathbf{2}} \mathbf{O}_{\mathbf{3}}$ & $\mathbf{M g O}$ & $\mathbf{M n O}_{\mathbf{2}}$ & $\mathbf{V}_{\mathbf{2}} \mathbf{O}_{5}$ & $\mathbf{L O I}$ \\
\hline Iron ore fines & 61.47 & 2.88 & 5.4 & 0.16 & 1.52 & 0.08 & 0.31 & 0.008 & 5.14 \\
Return fines & 54.66 & 8.89 & 5.73 & 10.79 & 1.6 & 1.62 & 0.081 & 0.012 & 1.21 \\
Calcined lime & 0.49 & 0 & 8.24 & 67.08 & 1.98 & 3.23 & 0.005 & 0.001 & 17.07 \\
Limestone & 0.13 & 0 & 4.81 & 50.44 & 0.58 & 1.61 & 0.005 & 0.001 & 40.74 \\
Dolomite & 0.12 & 0 & 3.21 & 31.21 & 0.09 & 20.43 & 0.005 & 0.01 & 44.09 \\
Coal & 1.98 & 0 & 4.42 & 2.84 & 1.80 & 0.41 & 0.07 & 0.001 & 85.36 \\
\hline
\end{tabular}

Table 3. Proximate analyses of coal (air-dry basis)/wt $\%$.

\begin{tabular}{cccc}
\hline $\mathbf{M}_{\mathbf{a d}}$ & $\mathbf{A}_{\mathbf{a d}}$ & $\mathbf{V}_{\mathbf{a d}}$ & $\mathbf{F C}_{\mathbf{a d}}$ \\
\hline 1.45 & 15.06 & 3.63 & 79.86 \\
\hline
\end{tabular}

Note: $\mathrm{M}_{\mathrm{ad}}$-moisture on air dry basis; $\mathrm{A}_{\mathrm{ad}}$ —ash on air dry basis; $\mathrm{V}_{\mathrm{ad}}$ —volatile matter on dry ash free; $\mathrm{FC}_{\mathrm{ad}}$-fixed carbon on air dry basis.

\subsection{Experimental Methods and Devices}

\subsubsection{Catalytic Reduction}

Catalytic reduction experiments are carried out in a tubular reduction furnace, and the experimental system is shown in Figure 2. It mainly includes three parts: gas distribution device, reaction device, and flue gas measuring device. In the gas supply system, the gas is stored in the high-pressure gas cylinder, and the flow is controlled by the rotor flowmeter. After the gas is mixed evenly in the mixing tank, it is passed into the reaction system. The reaction system is mainly composed of a quartz tube holding sinter catalyst and a reduction furnace. The inner diameter of the quartz tube is $35 \mathrm{~mm}$, and the height is $700 \mathrm{~mm}$. The gas used in the distribution system includes four kinds of gas, NO, CO, $\mathrm{O}_{2}$, and $\mathrm{N}_{2}$, which are, respectively, configured by high-pressure gas cylinders, controlled by glass rotor flowmeter, and mixed by a mixer and then passed into the quartz tube in the tubular reduction furnace. The composition of the gas in the high-pressure gas cylinder is as follows: $\mathrm{NO}$ standard gas ( $\mathrm{NO}$ concentration is $10 \mathrm{vol} \%$, balance gas is $\mathrm{N}_{2}$ ), CO standard gas (CO concentration is $10 \mathrm{vol} \%$, balance gas is $\mathrm{N}_{2}$ ) (provided by Wuhan Newred Special Gas Co., LTD., Wuhan, China), $\mathrm{O}_{2}$ standard gas (purity $99.9 \mathrm{vol} \%$ ), and $\mathrm{N}_{2}$ standard gas (purity 99.9 vol\%) (provided by Wuhan Minghui Gas Technology Co., LTD., Wuhan, China).

The sinter catalyst is put into the quartz tube, and then the quartz tube is placed in the reduction furnace. The reduction furnace is opened, and the sinter is heated to a predetermined temperature. During the heating process, nitrogen is used to protect the sinter. After reaching the specified temperature, the gas is switched to reduction gas, which flows in from below the quartz tube, passes through the sinter layer, and then flows out from the upper outlet, and is processed in the tail gas bottle before entering the atmosphere. The analysis system mainly uses a portable flue gas analyzer (PG-250, HORIBA, Kyoto, Japan) to measure the gas composition at the entrance and exit of the reaction system. The measurement accuracy of $\mathrm{O}_{2}$ is $\pm 2.0 \%$, and that of other gases is $\pm 1.0 \%$. During the experiment, when the data of the flue gas analyzer are roughly stable for $10 \mathrm{~min}$, the experimental data should be recorded to avoid interference and ensure the authenticity of the data. 


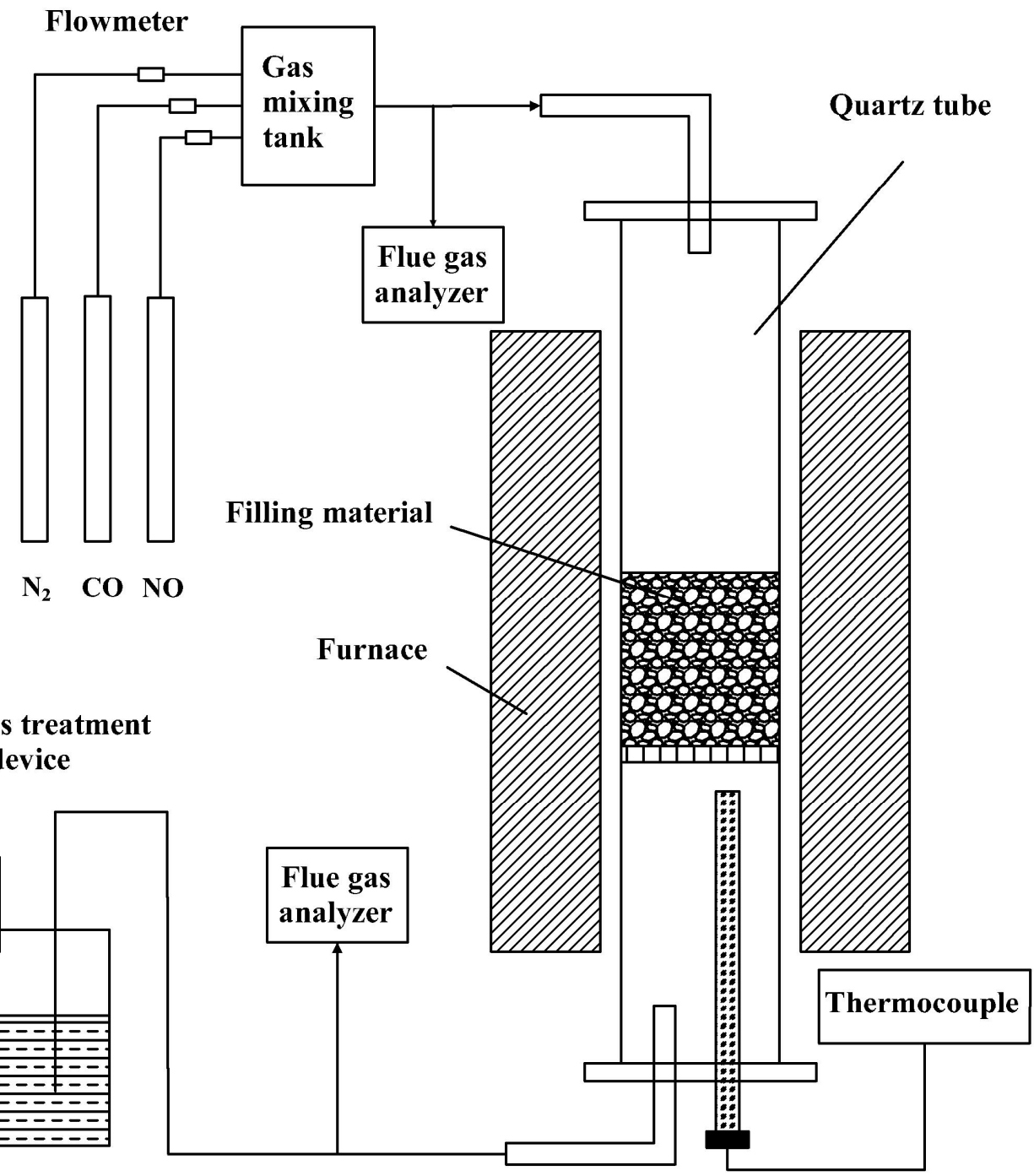

Figure 2. Schematic diagram of catalytic reduction experiment apparatus.

\subsubsection{Double-Layer Ignition Sintering}

The experimental device of double-layer ignition sintering was designed and developed by us. Its structure is shown in Figure 3, including gas fuel, ignition device, lower sintering cup, connecting device of upper and lower sintering cups, upper sintering cup, vacuum chamber, blower, and extractor fan. In order to investigate the effect of double-layer ignition sintering on the sinter indexes and emission concentration of flue gas pollutants in the sintering process under the same granulation conditions, the single-layer sintering experiment and double-layer ignition sintering experiment were carried out in the laboratory; the specific experimental scheme is shown in Table 4.

Sintering tests include proportioning, mixing, granulation, ignition, sintering, cooling, sieving, and quality testing of sinter. A single-layer sintering experiment adopts a conventional sintering method; the specific operation methods were as below. It took weight batching for raw materials matching, as given in Table 5 in the sintering process. After batching, the mixture was fully mixed and charged into a cylinder mixer $600 \mathrm{~mm}$ in diameter and $300 \mathrm{~mm}$ in length to granulate at $20 \mathrm{rpm}$ for $4 \mathrm{~min}$. The granulated mixture was then fed into the sintering pot. To protect the hearth, sintered ores with particle size of 10-16 mm were fed as hearth layer at the bottom of pot, of which the height was about $20 \mathrm{~mm}(1.0 \mathrm{Kg})$; the granulated mixture is distributed into the sinter cup, the material height of which was $720 \mathrm{~mm}$; the ignition temperature was $1050 \pm 50{ }^{\circ} \mathrm{C}$, the ignition time was $2 \mathrm{~min}$, and the negative pressure was $5 \mathrm{KPa}$. After the ignition, the negative pressure was 
adjusted to $10 \mathrm{KPa}$. After the sintering, it was cooled for 4 min under a negative pressure of $4 \mathrm{KPa}$. The experimental method of double-layer ignition and sintering is as follows: part of the granulated mixture was placed in the lower sinter cup. After loading, the upper layer mixture was ignited with natural gas for $1.5 \mathrm{~min}$ at $1050{ }^{\circ} \mathrm{C}$ under the suction pressure of $5 \mathrm{KPa}$. After the ignition, the negative pressure was adjusted to $10 \mathrm{KPa}$. When the lower layer was sintered for 5-10 $\mathrm{min}$, the rest of the granulated mixture was quickly distributed into the upper sintering cup for the upper ignition. After loading, the upper layer mixture was ignited with natural gas for $1.5 \mathrm{~min}$ at $1050{ }^{\circ} \mathrm{C}$ under the suction pressure of $10 \mathrm{KPa}$. After the ignition, the negative pressure was adjusted to $10 \mathrm{KPa}$. During the sintering experiment, the flue gas analyzer (PG-250, HORIBA, Kyoto, Japan) was used to detect the composition of sintering flue gas, including the concentration of $\mathrm{NO}_{\mathrm{x}}, \mathrm{O}_{2}, \mathrm{CO}_{2}, \mathrm{CO}$, and other gases, and record the data every $5 \mathrm{~s}$.

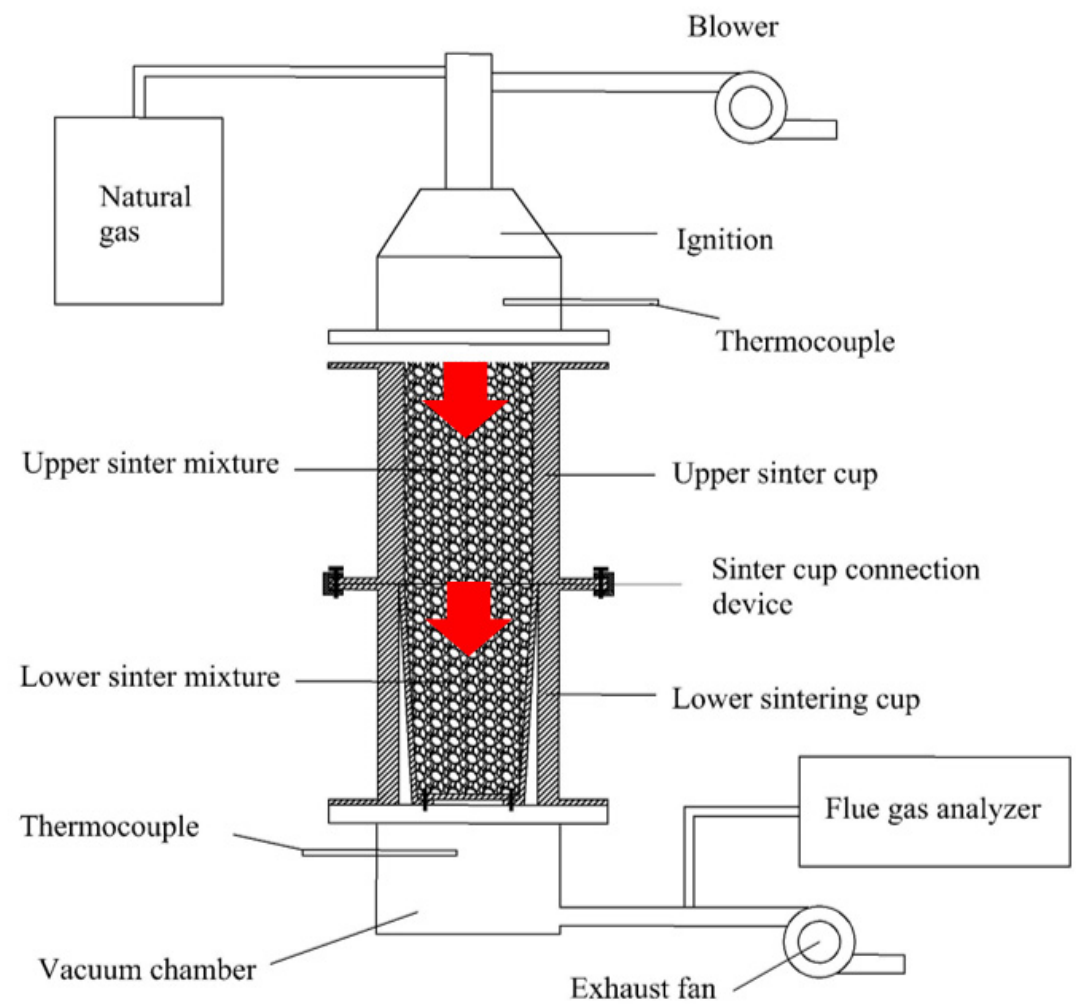

Figure 3. Schematic diagram of double-layer ignition sintering experiment device.

Table 4. Experimental conditions.

\begin{tabular}{cccc}
\hline Test Number & $\begin{array}{c}\text { Lower Layer } \\
\text { Height/mm }\end{array}$ & $\begin{array}{c}\text { Upper Layer } \\
\text { Height/mm }\end{array}$ & $\begin{array}{c}\text { Ignition Time } \\
\text { Interval/min }\end{array}$ \\
\hline 1 & 720 & 0 & - \\
2 & 320 & 400 & 5 \\
3 & 320 & 400 & 7.5 \\
4 & 320 & 400 & 10 \\
5 & 360 & 360 & 5 \\
6 & 400 & 320 & 5 \\
\hline
\end{tabular}

Table 5. Composition of sintering mixture/wt $\%$.

\begin{tabular}{cccccccc}
\hline $\begin{array}{c}\text { Raw } \\
\text { Materials }\end{array}$ & $\begin{array}{c}\text { Iron Ore } \\
\text { Fines }\end{array}$ & Return Fines & Coal & $\begin{array}{c}\text { Calcined } \\
\text { Lime }\end{array}$ & Limestone & Dolomite & Total Mass \\
\hline Mass fraction & 56.0 & 25.0 & 4.0 & 3.0 & 5.5 & 6.5 & 100.0 \\
\hline
\end{tabular}




\subsection{Calculation of $N O x$}

In the process of catalytic reduction, the conversion rate of nitric oxide is calculated in Equation (1):

$$
\eta_{N O}=\frac{c_{N O}^{\prime}}{c_{N O}}
$$

where $\eta_{\mathrm{NO}}$ is the conversion of $\mathrm{NO}, \% ; c_{N O}$ is the concentration of $\mathrm{NO}$ at the inlet, $\mathrm{mg} / \mathrm{m}^{3}$; and $c_{N O}^{\prime}$ is the concentration of $\mathrm{NO}$ at the outlet, $\mathrm{mg} / \mathrm{m}^{3}$.

Refer to GB/T 16157-1996, "Determination of particulate matter and sampling of gaseous pollutants in stationary source exhaust" and Ministry of Ecology and Environment, PRC "Opinions on Promoting ultra-Low Emissions in Iron and Steel Industry". In the sintering process, the nitrogen oxide concentration in flue gas is based on the $\mathrm{NO}_{\mathrm{x}}$ concentration under the $16 \%$ baseline oxygen content $\left(c_{N O_{x}}^{\prime}\right)$, and the calculation formula is shown in Equation (2).

$$
c_{\left(N O_{x}\right)}^{\prime}=\frac{c_{\left(N O_{x}\right)} \times(21-16)}{\left(21-c_{\left(O_{2}\right)}\right)}
$$

where, $c_{\left(\mathrm{NO}_{x}\right)}^{\prime}$ is the $\mathrm{NO}_{\mathrm{x}}$ concentration under the $16 \%$ baseline oxygen content, $\mathrm{mg} / \mathrm{m}^{3}$; $c_{\left(N O_{x}\right)}$ is the actual concentration of $\mathrm{NO}_{\mathrm{x}}$ in the sintering process, $\mathrm{mg} / \mathrm{m}^{3} ; \mathrm{c}_{\left(\mathrm{O}_{2}\right)}$ is the actual volume fraction of flue gas $\mathrm{O}_{2}, \%$.

\subsection{Sintering Indices}

After sintering, the indexes were tested, including particle size composition, yield, drum index, and fall strength. The testing criteria are as follows: (1) particle size and particle size composition test refer to ISO4701; (2) refer to GB8209-87 for strength test of drum; (3) standard test of shatter strength (refer to JIS8711-77); The calculation methods of these sintering indices are shown in Table 6.

\begin{tabular}{|c|c|c|c|}
\hline Scheme & Equation & Unit & Symbols \\
\hline Yield & $\eta=\left(m_{0}-m_{1} / m_{0}\right) \times 100 \%$ & $\%$ & $\begin{array}{l}\mathrm{m}_{0} / \mathrm{kg}-\text { mass of sintered ore } \\
\text { without hearth } \\
\mathrm{m}_{1} / \mathrm{kg} \text {-mass of return fines } \\
(<5 \mathrm{~mm}) \text { after the shatter test }\end{array}$ \\
\hline Shatter strength & $\mathrm{F}=\mathrm{m}_{1} / \mathrm{m}_{0} \times 100 \%$ & $\%$ & $\begin{array}{l}\mathrm{m}_{0} / \mathrm{kg}-\text { mass of sintered ore } \\
\mathrm{m}_{1} / \mathrm{kg}-\text { mass of sintered ore } \\
(>10 \mathrm{~mm}) \text { after the shatter test }\end{array}$ \\
\hline Drum index & $\mathrm{T}=\mathrm{m}_{1} / \mathrm{m}_{0} \times 100 \%$ & $\%$ & $\begin{array}{c}\mathrm{m}_{0} / \mathrm{kg}-\text { mass of sample } \\
\mathrm{m}_{1} / \mathrm{kg} \text { - } \mathrm{mass} \text { of }>6.3 \mathrm{~mm} \text { sample } \\
\text { after drum test }\end{array}$ \\
\hline
\end{tabular}

Table 6. Calculation equations for yield and qualities index of sintered ore.

\section{Results and Discussion}

\subsection{Catalytic Reduction}

\subsubsection{Effect of Temperature on Catalytic Reduction of NO in Sintered Ore}

In order to explore the strength of sinter catalysis under different reaction temperatures, this experiment studied the influence of different temperatures on the catalytic reduction of $\mathrm{NO}$ in sinter under the conditions of particle size of $0.2-1 \mathrm{~mm}$, space velocity ratio of $3000 \mathrm{~h}^{-1}$, gas flow rate of $1 \mathrm{~L} / \mathrm{min}, \mathrm{CO}$ concentration of $0.3 \%$, and $\mathrm{NO}$ concentration of $669.87 \mathrm{mg} / \mathrm{m}^{3}$. The experiment without catalyst under the same conditions was conducted as a blank control, and the results are shown in Figure 4 . The results showed that, in the blank controlled test, when the temperature is lower than $600^{\circ} \mathrm{C}, \mathrm{CO}$ has no reduction effect on the reduction of $\mathrm{NO}$. When the temperature reaches $800^{\circ} \mathrm{C}$, the $\mathrm{NO}_{\mathrm{x}}$ conversion rate increases to $12.2 \%$; when the temperature reaches $100{ }^{\circ} \mathrm{C}$, the $\mathrm{NO}$ conversion rate reaches 
$45.65 \%$. It indicates that the reduction of $\mathrm{NO}$ by $\mathrm{CO}$ can only occur at high temperature above $600{ }^{\circ} \mathrm{C}$, and it is difficult to proceed at low temperature.

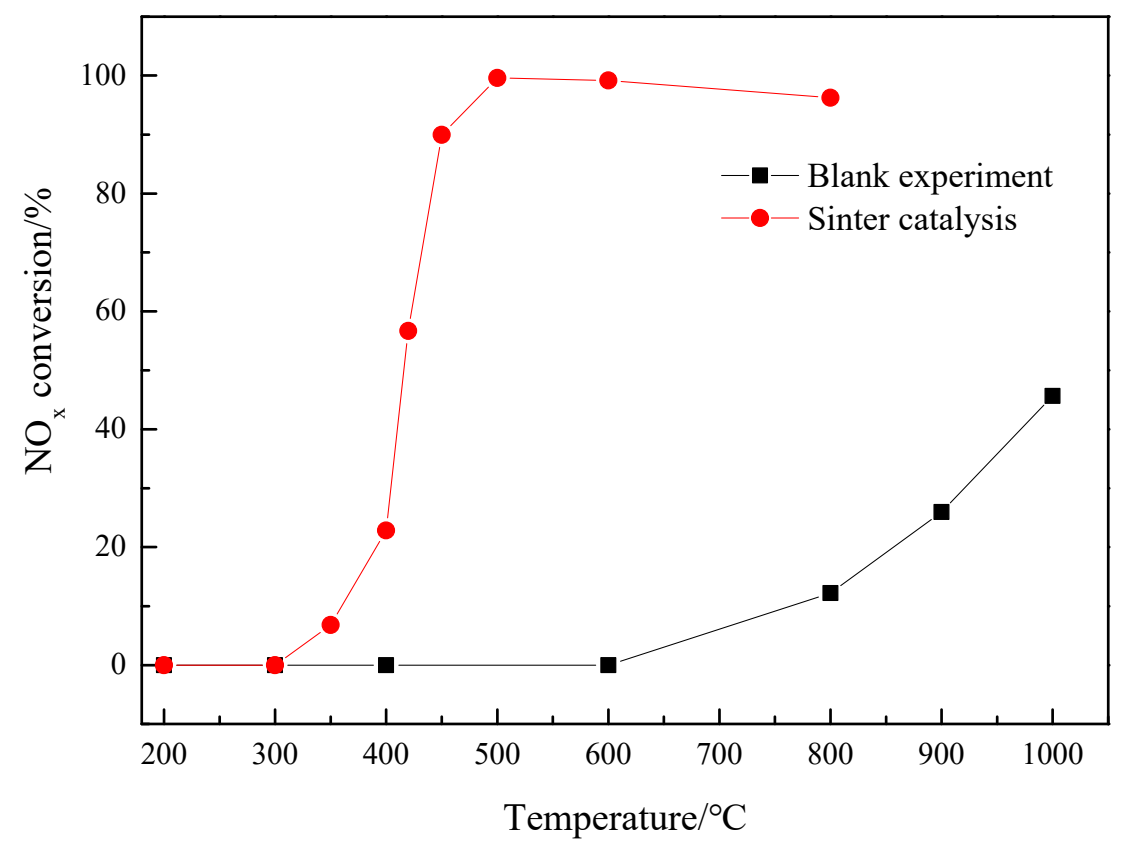

Figure 4. Effect of temperature on catalytic reduction of NO in sinter ores.

In the temperature range of $200-800{ }^{\circ} \mathrm{C}$, with the increase in temperature, the conversion of NO catalyzed by sintered ore firstly increases rapidly and then decreases slowly. In the temperature range of $400-500{ }^{\circ} \mathrm{C}$, the conversion of $\mathrm{NO}$ is greatly affected by temperature. When the reaction temperature rises from $400{ }^{\circ} \mathrm{C}$ to $500{ }^{\circ} \mathrm{C}$, the conversion of NO increases from $22.82 \%$ to $99.58 \%$. The apparent reaction order of CO increases from $22.82 \%$ at $400{ }^{\circ} \mathrm{C}$ to $99.58 \%$ at $500{ }^{\circ} \mathrm{C}$. This can be attributed to the low adsorption constants of $\mathrm{CO}$ and $\mathrm{NO}$ below $400{ }^{\circ} \mathrm{C}$; as the temperature continues to increase, the adsorption rate of $\mathrm{CO}$ and $\mathrm{NO}$ increases, and the reaction rate accelerates [39]. When the reaction temperature exceeds $500{ }^{\circ} \mathrm{C}$, the conversion of $\mathrm{NO}$ decreases slightly. It can be seen that under the catalytic action of sintered ore, the reduction temperature of $\mathrm{CO}$ is much lower than that without sintered ore, and the conversion rate of $\mathrm{NO}$ is much higher than that without sintered ore. To sum up, the catalytic reduction effect of sintered ore on NO is obvious, and the optimum temperature for catalytic reduction of $\mathrm{NO}$ by sinter is $500{ }^{\circ} \mathrm{C}$.

The reaction process of $\mathrm{NO}$ reduction by $\mathrm{CO}$ on sinter surface can be divided into two parts: first, $\mathrm{FeO}$ generated by $\mathrm{CO}$ reduction reaction of $\mathrm{Fe}_{2} \mathrm{O}_{3} / \mathrm{Fe}_{3} \mathrm{O}_{4}$ in sinter is used as a reducing agent to reduce $\mathrm{NO}$ to $\mathrm{N}_{2}$; second, under the catalysis of metal oxide of sinter, $\mathrm{CO}$ directly reduces $\mathrm{NO}$ to $\mathrm{N}_{2}$. $\mathrm{CO}$ in the system can reduce metal oxides to lower oxides and then reduce NO. The reduction reaction mechanism of NO on iron oxide is as follows: (1) Fe-bearing minerals such as calcium ferrite were reduced by $\mathrm{CO}$ to form ferrous oxide; (2) NO is adsorbed on low iron oxide and REDOX reaction is carried out; (3) NO reacts with ferrous oxide to form $\mathrm{N}_{2}$ [40]. Meanwhile, the concentrations of $\mathrm{NO}$ and $\mathrm{CO}$ decreased owing to the catalytic reaction between $\mathrm{NO}-\mathrm{CO}$ and $\mathrm{Ca}-\mathrm{Fe}$ oxides [35]. In the process of catalytic reduction of $\mathrm{NO}$ to $\mathrm{N}_{2}$, there was competitiveness between $\mathrm{CO}$ and $\mathrm{NO}$, as they were absorbed to the surface of calcium ferrite. Since calcium ferrite had the structure of spinel, and CO had fewer electrons in their valence shell than NO, it was easily absorbed on calcium ferrite, which was advantageous to reduce calcium ferrite [41]. The generation of oxygen vacancies in iron oxide had a strong activity lattice of $\mathrm{O}^{2-}$, which caused the reduction of $\mathrm{NO}[40]$. 


\subsubsection{Effect of Space Velocity on Catalytic Reduction of NO in Sintered Ore}

Space velocity refers to the amount of gas treated per unit time per unit volume of catalyst, which is an important parameter to evaluate the performance of catalyst. Under the conditions of gas flow rate of $1 \mathrm{~L} / \mathrm{min}, \mathrm{CO}$ concentration of $0.3 \%$, NO concentration of $500 \mathrm{ppm}$, and reaction temperature of $500{ }^{\circ} \mathrm{C}$, the influence of space velocity on catalytic reduction of NO in sinter was studied with sinter of $0.2-1 \mathrm{~mm}$ as catalyst. The results are shown in Figure 5. The results showed that the conversion rate of NO decreases with the increase in space velocity.

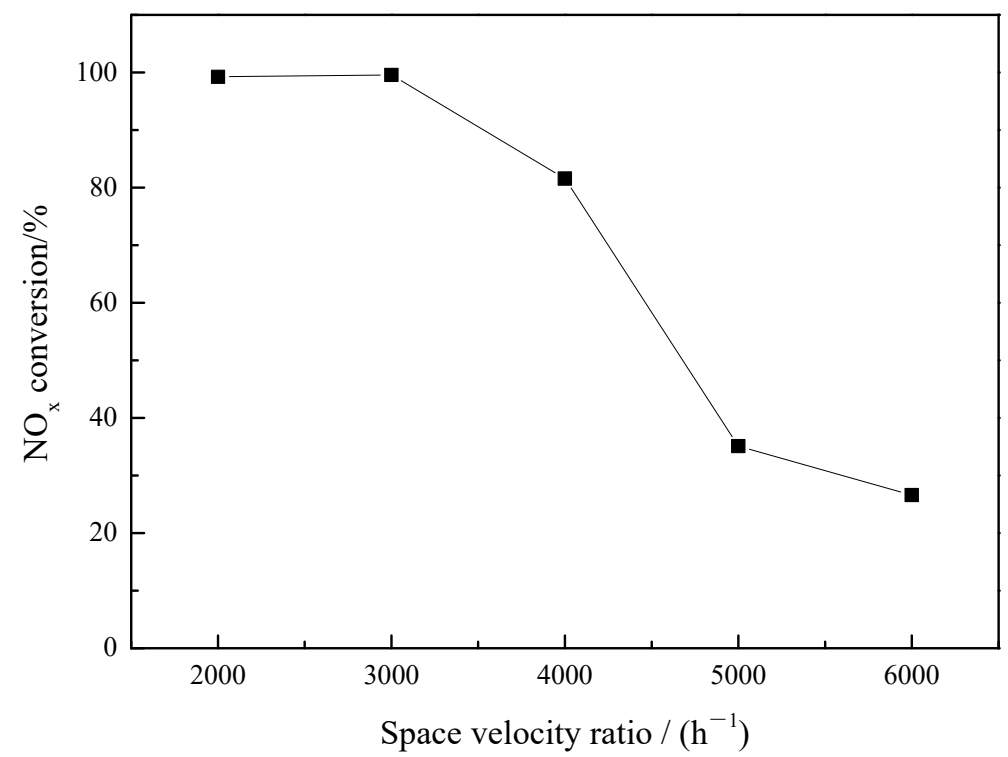

Figure 5. Effect of Space velocity ratio on catalytic reduction of NO in sintered ore.

As can be seen from Figure 5, when the airspeed increases from $2000 \mathrm{~h}^{-1}$ to $3000 \mathrm{~h}^{-1}$, the conversion rate of NO does not change much, which is above $99 \%$. When the airspeed increased to $5000 \mathrm{~h}^{-1}$, the NO conversion rate decreased sharply to $35.11 \%$. When the space speed increases to $6000 \mathrm{~h}^{-1}$, the conversion rate of NO further decreases to $26.6 \%$. This is because when the space velocity increases, the amount of NO catalyzed by sintered ore per unit volume increases, the contact between $\mathrm{NO}$ gas and sinter is insufficient, and the reaction time decreases, so the conversion rate of NO decreases. If the space speed is too low, the amount of catalyst is too large, and the cost is high; if the airspeed is too high, the conversion rate of $\mathrm{NO}$ decreases, and $\mathrm{NO}$ emissions cannot be effectively reduced. Therefore, $3000 \mathrm{~h}^{-1}$ airspeed is selected after comprehensive consideration.

During the sintering experiment, the $\mathrm{CO}$ concentration in the waste gas can reach about $2 \%$, and the concentration of $\mathrm{NO}$ is $400-600 \mathrm{ppm}$ [42]. However, the CO concentration in the actual sintering combustion zone can reach about $6 \%$, which can meet the consumption of reduced NO. The temperature of combustion zone and sinter zone can meet the temperature condition of $\mathrm{CO}$ reduction of NO catalyzed by sintered ore [43]. At the same time, near the fuel combustion interface in the combustion zone, a large amount of oxygen is consumed to generate $\mathrm{CO}_{2}, \mathrm{CO}$, and $\mathrm{NO}_{x}$ gases. After the gas encounters the surrounding hightemperature sinter, the reduction reaction of $\mathrm{CO}$ and $\mathrm{NO}$ will occur under the catalytic action of sintered ore, which is conducive to reducing the concentration of $\mathrm{NO}$ in the flue gas.

\subsection{Double-Layer Ignition Sintering}

\subsubsection{Sintering Performance}

The practical effect of the layer height proportion and ignition time interval on the size composition was studied by the sintering pot experiment, and other sintering indexes were tested meanwhile. The sintering indexes in the single-layer sintering experiment were in- 
vestigated. Under the conditions of layer height proportion of 320/400 $\mathrm{mm}$ (lower/upper), the sintering indexes under different ignition time interval were studied; under the conditions of ignition time interval of $5 \mathrm{~min}$, the sintering indexes under different layer height proportion (lower/upper) were studied, and the results are shown in Table 7 and Figure 6.

Table 7. Effect of different layer height proportions and ignition time interval on the size composition of sintered ores.

\begin{tabular}{ccccccc}
\hline $\begin{array}{c}\text { Size Distribution of } \\
\text { Sintered Ore }\end{array}$ & $\mathbf{1}$ & $\mathbf{2}$ & $\mathbf{3}$ & $\mathbf{4}$ & $\mathbf{5}$ & $\mathbf{6}$ \\
\hline$>40 \mathrm{~mm} / \%$ & 2.73 & 2.38 & 2.61 & 3.09 & 2.44 & 1.12 \\
$40 \sim 25 \mathrm{~mm} / \%$ & 7.47 & 9.96 & 9.91 & 10.57 & 12.67 & 11.59 \\
$25 \sim 16 \mathrm{~mm} / \%$ & 12.66 & 14.72 & 13.59 & 16.18 & 13.27 & 14.58 \\
$16 \sim 10 \mathrm{~mm} / \%$ & 16.30 & 16.09 & 17.96 & 16.92 & 16.03 & 16.17 \\
$10 \sim 5 \mathrm{~mm} / \%$ & 21.68 & 18.65 & 18.33 & 16.64 & 17.87 & 17.94 \\
$<5 \mathrm{~mm} / \%$ & 39.16 & 38.21 & 37.60 & 36.61 & 37.72 & 38.60 \\
Total/\% & 100.00 & 100.00 & 100.00 & 100.00 & 100.00 & 100.00 \\
\hline
\end{tabular}

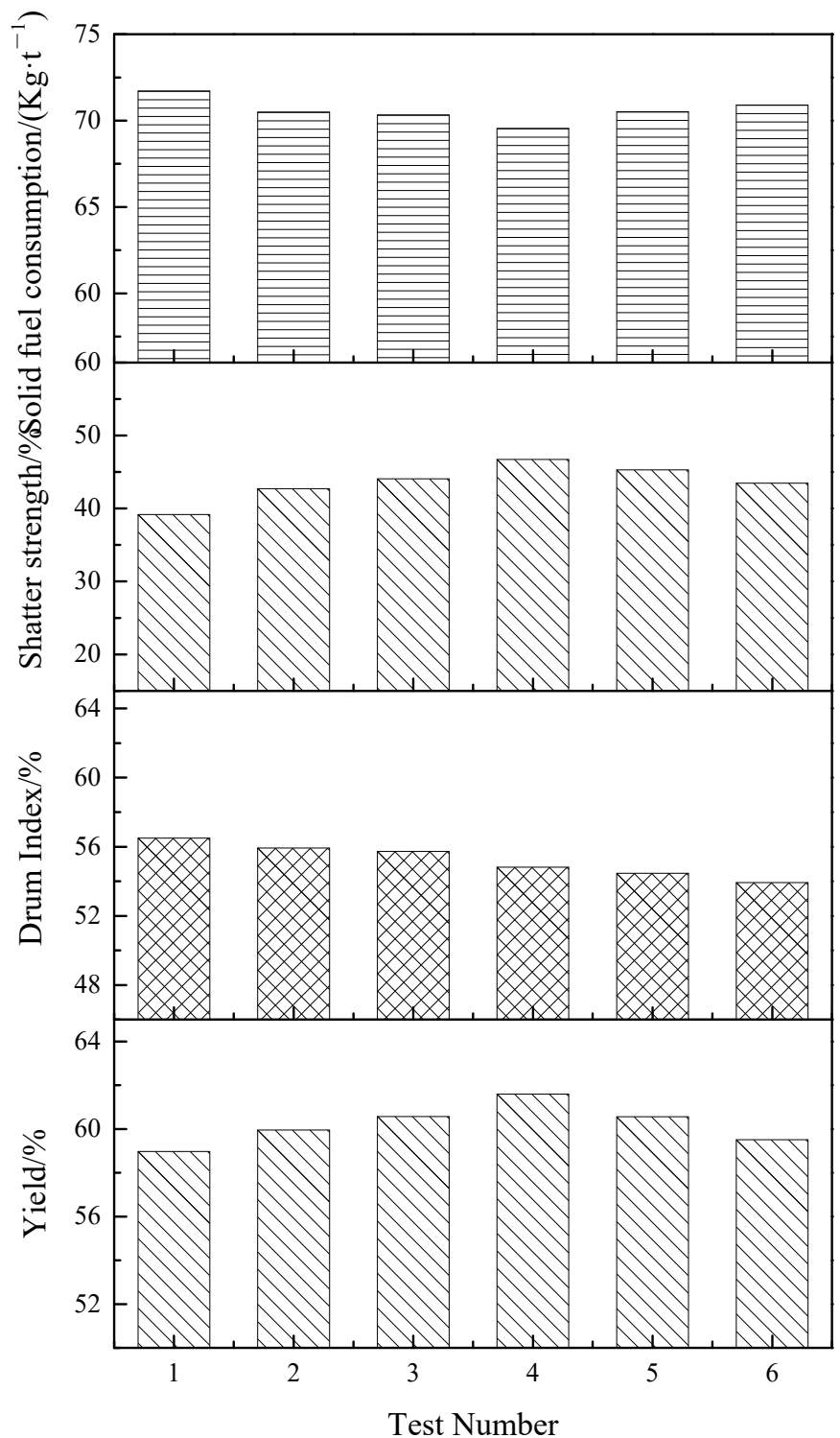

Figure 6. Sintering indexes at different ignition time intervals and layer height proportions. 
Table 7 showed that as the ignition time interval lengthened and the height of the lower layer increased, the particle size distribution of sinter is more reasonable, with the content of coarse grains $(>5 \mathrm{~mm})$ increasing and that of fine grains $(<5 \mathrm{~mm})$ decreasing, which has a favorable effect on blast furnace smelting $[44,45]$. The production practice of blast furnace in China shows that when sinter powder content $(<5 \mathrm{~mm})$ increases by $10 \%$, blast furnace output decreases by $6-8 \%$, and coke ratio increases by $0.5 \%$ [46]. At the same time, the particle size distribution of sintered ore is more uniform, and the content of coarse grains $(5-40 \mathrm{~mm})$ increases, indicating that the physical strength of sintered ore has been improved to a certain extent.

Figure 6 showed that, compared with single-layer sintering, on the whole, the sinter yield of double-layer ignition sintering is increased, solid fuel consumption is slightly reduced, falling strength is slightly increased, and drum strength is slightly decreased. This indicated that double-layer ignition sintering had a certain effect on reducing sintering solid consumption and improving the yield of sinter but was not conducive to the drum strength of sinter. This is because, in the double-layer ignition sintering process, the upper sintering and lower sintering processes were carried out at the same time, and the heat carried by the upper sintering flue gas entered the lower sintering layer, increasing the temperature of the lower sintering material layer and making the utilization rate of the heat in the flue gas inside the material layer increasing, which was beneficial to improve the quality of the sintered ore, but due to the simultaneous existence of two combustion zones, the air permeability in the sintering material layer was reduced, the lower sintering fuel was not fully burned, and the heat was not completely released, so that the temperature of the lower sintering combustion zone cannot be increased. The amount of liquid phase generated in sinter was reduced, which was not conducive to improving the quality of sinter.

As the ignition time interval lengthens from 5 to $10 \mathrm{~min}$, the yield increases slightly, the solid fuel consumption decreases slowly, the shatter strength increases slightly, and the drum index decreases slowly. When the ignition time interval is $5 \mathrm{~min}$, the yield, drum strength, shatter strength, and solid fuel consumption were 59.96\%, 55.93\%, 42.69\%, and 70.49\%, respectively. When the ignition time interval increased to $10 \mathrm{~min}$, the yield, drum strength, shatter strength, and solid fuel consumption reached $61.60 \%, 54.82 \%, 46.75 \%$, and $69.55 \%$, respectively. It means that appropriately prolonging the ignition time interval is conducive to improving the yield and falling strength of sinter and reducing the solid burn up of sinter, but the drum index of sinter decreases. Therefore, on the condition that the drum index of sinter is guaranteed, the ignition time interval can be appropriately prolonged.

As the height of the lower layer increases from 320 to $400 \mathrm{~mm}$, the yield decreases slightly, the solid fuel consumption increases slowly, the shatter strength increases slightly, and the drum index decreases slowly. This indicates that the increase in the height of the lower layer is not conducive to the progress of the double-layer ignition sintering process, which will lead to a decrease in the sinter yield, the shatter strength, and the drum index and also make the sintering solid fuel consumption slightly increase. Therefore, in order to improve the sintering index, the proportion of the lower layer height should be appropriately reduced.

\subsubsection{Sintering Flue Gas}

In order to investigate the effect of double-layer ignition sintering on the emission concentration of flue gas pollutants in the sintering process, the emission concentration of flue gas pollutants in the single-layer sintering experiment were investigated. Under the conditions of layer height proportion of $320 / 400 \mathrm{~mm}$ (lower/upper), the emission concentration of flue gas pollutants under different ignition time interval were studied. Under the conditions of ignition time interval of $5 \mathrm{~min}$, the emission concentration of flue gas pollutants under different layer height proportion (lower/upper) were studied, and the results are shown in Figures 7-10. 

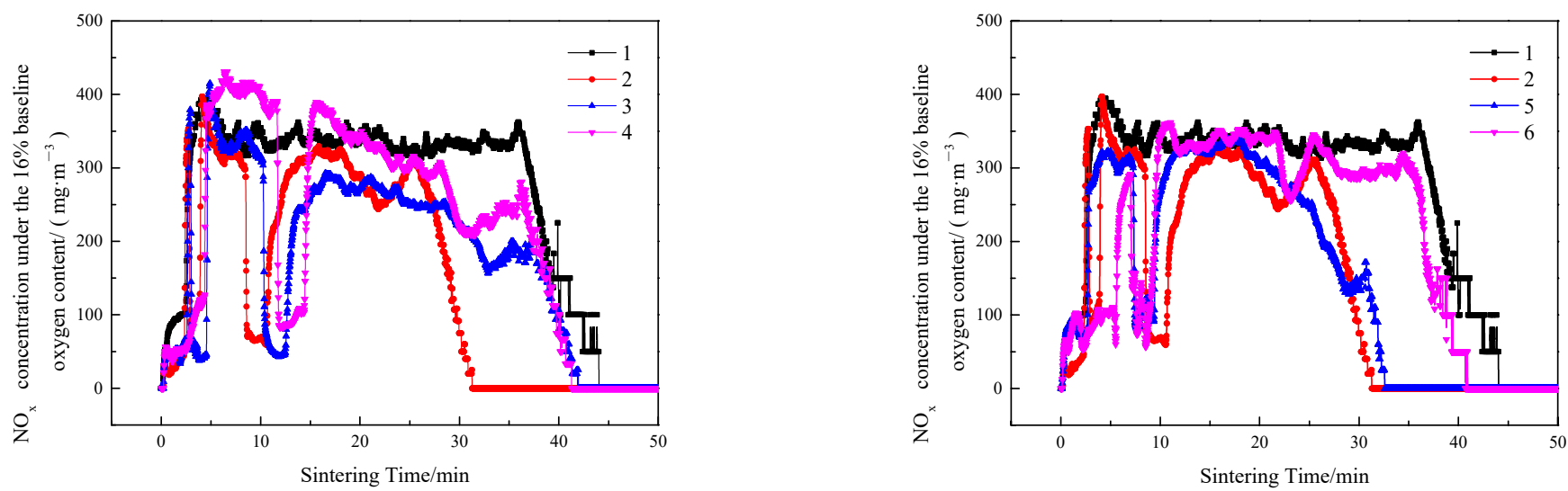

Figure 7. $\mathrm{NO}_{\mathrm{x}}$ emissions of sintering flue gas at different ignition time intervals and layer height proportions.
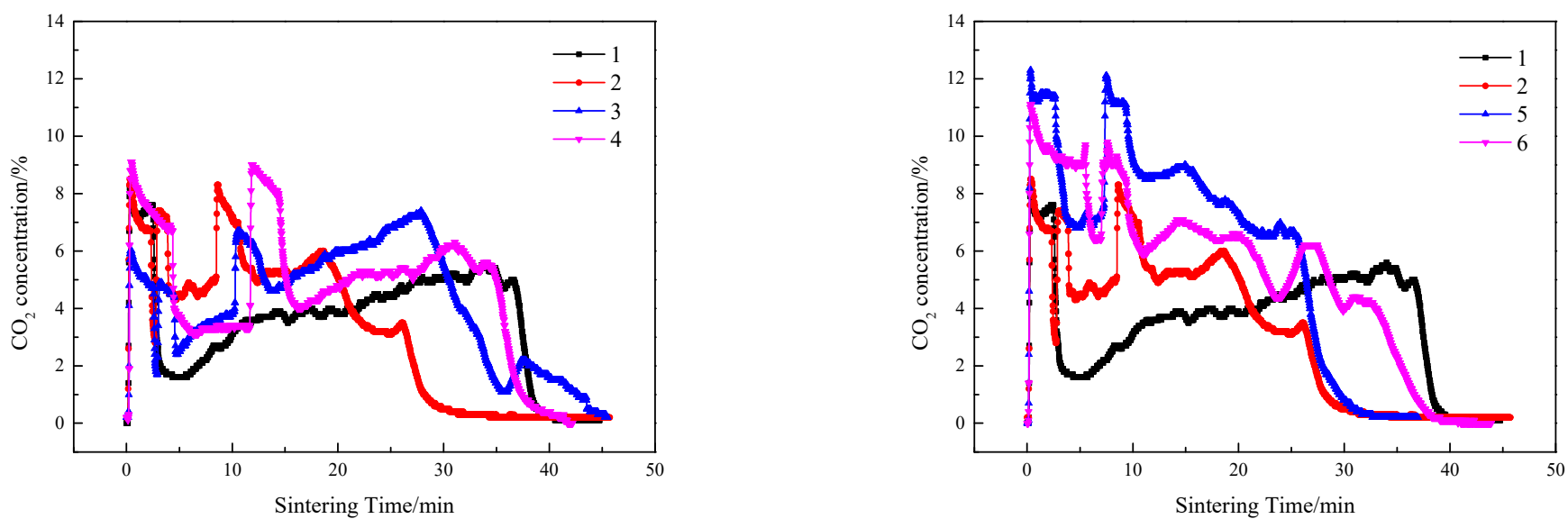

Figure 8. $\mathrm{CO}_{2}$ emissions of sintering flue gas at different ignition time intervals and layer height proportions.
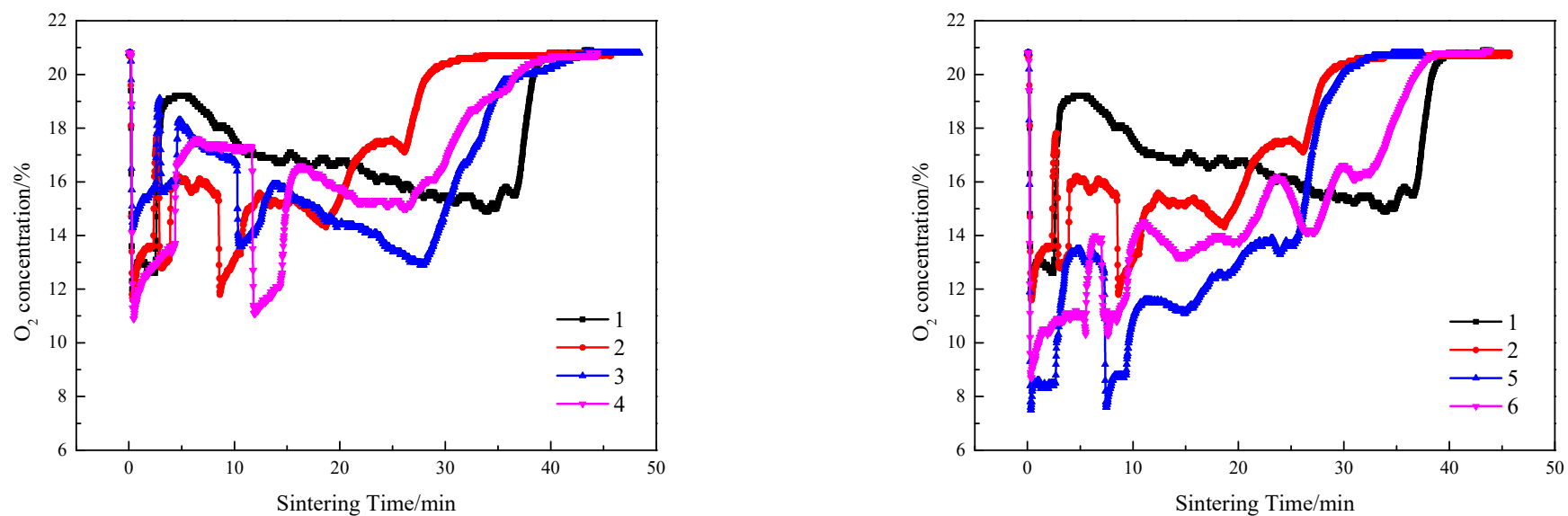

Figure 9. $\mathrm{O}_{2}$ emissions of sintering flue gas at different ignition time intervals and layer height proportions. 

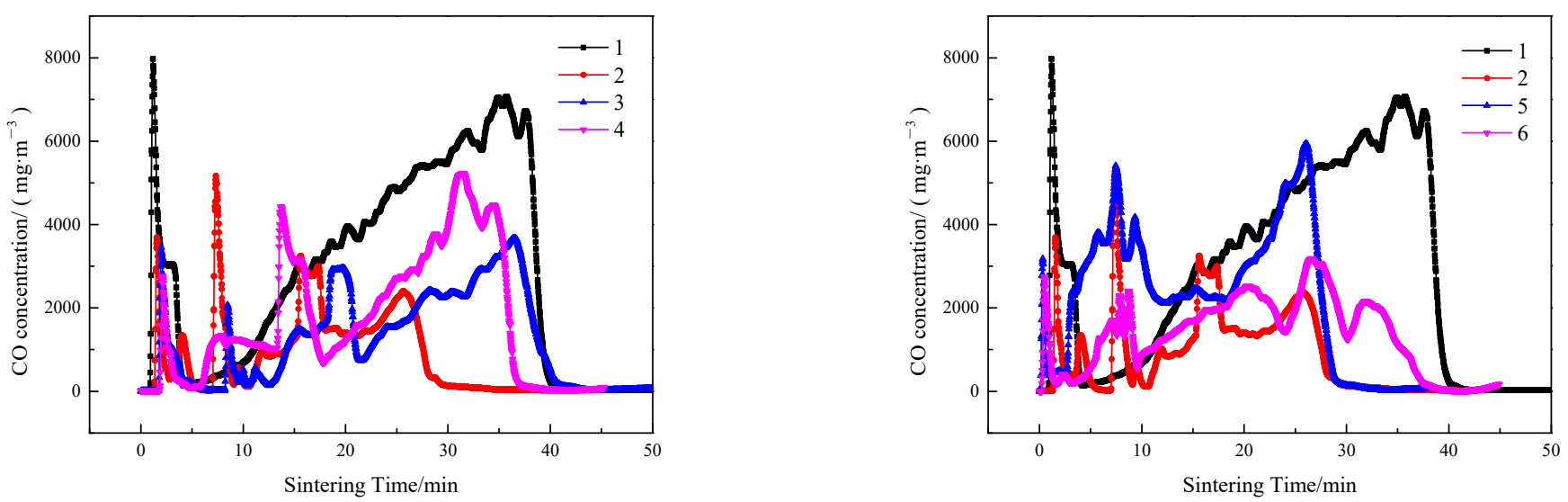

Figure 10. CO emissions of sintering flue gas at different ignition time intervals and layer height proportions.

As shown schematically in Figures 7-10, in contrast to the single-layer sintering, $\mathrm{NO}_{\mathbf{x}}$ concentration under the $16 \%$ baseline oxygen content $\left(c_{N O_{x}}^{\prime}\right)$ in the flue gas of double-layer ignition sintering is reduced to a certain extent. Under the conditions of layer height proportion of $320 / 400 \mathrm{~mm}$ (lower/upper), with the extension of the ignition time interval, the total sintering time increases gradually, $c_{N O_{x}}^{\prime}$ increases, and the generation time of nitrogen oxide also increases gradually, indicating that the extension of the ignition time is not conducive to the emission reduction of $\mathrm{NO}_{\mathrm{x}}$ in the whole sintering process. When the ignition time interval is $5 \mathrm{~min}, c_{N O_{x}}^{\prime}$ in the early stage of double-layer ignition and sintering process is slightly lower than that of single-layer sintering, and the generation time of $\mathrm{NO}_{x}$ is greatly shortened. This is because, in the process of double-layer ignition and sintering, the upper and lower sintering material layers are sintered down at the same time, resulting in the overall sintering time is greatly shortened. The $\mathrm{NO}_{\mathbf{x}}$ generated in the upper sintering process are partially decomposed and reduced when passing through the lower sintering combustion zone, which reduces the emission of nitrogen oxides [4]. At the same time, the oxygen content in the upper sintering flue gas is low and contains a certain concentration of $\mathrm{CO}$ and a large amount of $\mathrm{CO}_{2}$, leading to a reduction in $\mathrm{NO}_{x}$ production in the lower sintering process [47,48]. Metal oxides in sinter, such as $\mathrm{Fe}_{2} \mathrm{O}_{3}, \mathrm{Fe}_{3} \mathrm{O}_{4}$, and calcium ferrite, have different degrees of catalytic effect on the removal of $\mathrm{NO}$ by $\mathrm{CO}$ reduction $[35,40,49]$. When the ignition time interval is extended to $10 \mathrm{~min}$, the formation time of nitrogen oxide is gradually prolonged, which is due to the late ignition time of the upper sintering, while the lower part has been a large part of the sintering, and the material permeability of the lower layer is gradually reduced, resulting in the upper sintering speed slowed down, so the overall sintering time is longer than the ignition time interval of $5 \mathrm{~min}$.

Compared with single-layer sintering, the $\mathrm{CO}_{2}$ concentration in flue gas of doublelayer ignition sintering was higher, and the $\mathrm{O}_{2}$ concentration was lower. In the early stage of sintering, because only the lower sintering process was carried out, the height of the material layer was lower, the permeability of the material layer was better, and the fuel combustion rate was increased. When the upper layer was ignited, the sintering processes of the upper and lower layers were carried out at the same time, the permeability of the sintering material layer decreased, resulting in a decline in fuel combustion rate, and upper sintering flue gas entered the lower sintering, which caused the lower sintering of oxygen to decrease, the content of $\mathrm{CO}_{2}$ and $\mathrm{CO}$ to increase, the oxidizing atmosphere in the sintering material layer to weaken, and the lower combustion zone to form a local reducing atmosphere, which has a significant effect on decreasing $\mathrm{NO}$ [50]. The $\mathrm{NO}_{x}$ in the material layer is reduced and decomposed by $\mathrm{CO}$ under the catalysis of the hot sintered ore, thereby reducing the emission concentration of $\mathrm{NO}_{x}[4]$. At the same time, $\mathrm{CO}$ generated by sintering in the upper layer is burned again and consumed by REDOX reaction when passing through the lower layer sintering process; therefore, the content of carbon monoxide in the flue gas of double-layer ignition sintering is lower. 


\subsubsection{Mechanism of $\mathrm{NO}_{x}$ Degradation in Double-Layer Ignition Sintering}

A possible mechanism for the degradation of $\mathrm{NO}_{x}$ by double-layer ignition sintering is shown in Figure 11. This study changed the traditional single-layer ignition sintering to double-layer ignition sintering. In the double-layer ignition sintering process, the upper and lower sintering materials are sintered at the same time, and two combustion zones exist at the same time, which increases the width of the combustion zone inside the entire sintering material layer. The oxidizing atmosphere in the upper sintering flue gas is weakened, and the high-temperature hot sintered ore in the lower layer provides favorable conditions for catalytic reduction of $\mathrm{NO}_{\mathrm{x}}$. The use of sintered ore to catalytically reduced the $\mathrm{NO}_{\mathrm{x}}$ in the flue gas at high temperatures enables the $\mathrm{NO}_{\mathrm{x}}$ in the upper sintering flue gas to be reduced and decomposed when passing through the lower combustion zone. At the same time, when the upper layer sintering flue gas with lower oxygen content passed through the lower layer sintering, the $\mathrm{NO}_{x}$ conversion rate of the lower layer sintering fuel was reduced, thereby reducing the nitrogen oxide concentration during the entire sintering process.

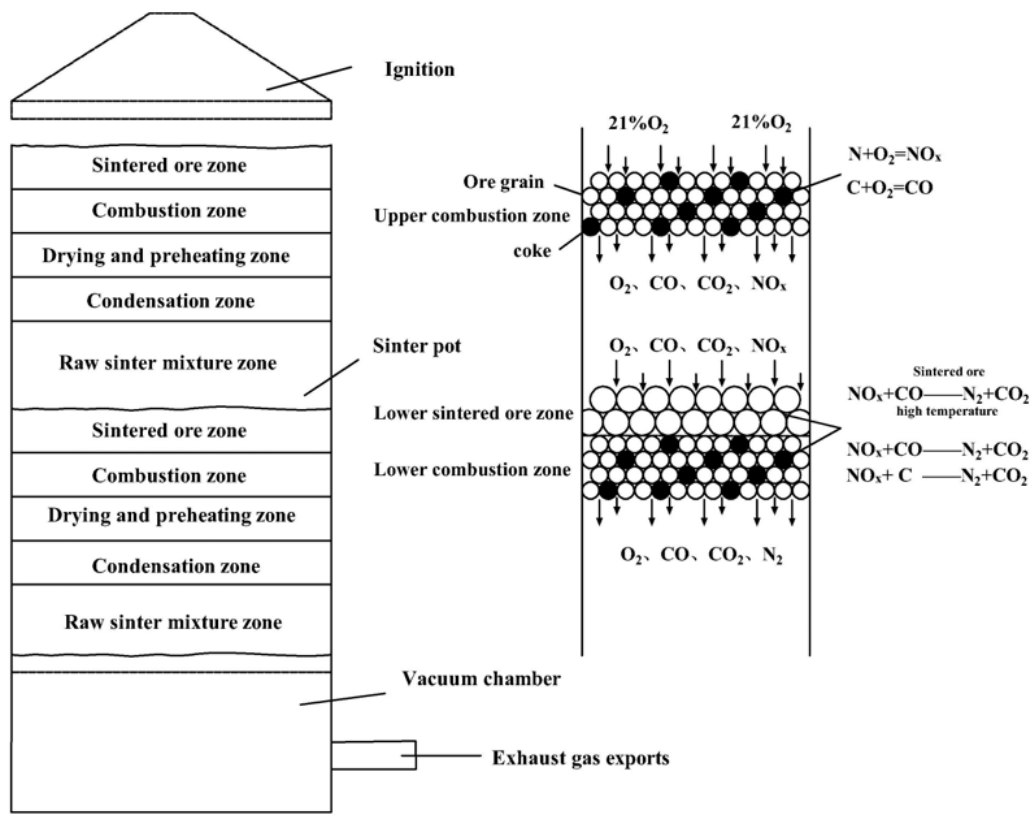

Figure 11. Schematic diagram of $\mathrm{NO}_{x}$ degradation mechanism of double-layer ignition sintering.

\section{Conclusions}

(1) The sintered ores are beneficial to promote the reaction process of $\mathrm{CO}$ reducing $\mathrm{NO}$. The reduction of $\mathrm{NO}$ by CO can only occur at high temperature above $600{ }^{\circ} \mathrm{C}$, and it is difficult to proceed at low temperature. When sinter is used as catalyst, the conversion rate of $\mathrm{NO}$ reduced by sintered ore increased significantly, reaching $99.58 \%$ at $500{ }^{\circ} \mathrm{C}$.

(2) Compared with single-layer sintering, the sinter yield of double-layer ignition sintering is increased, solid fuel consumption is slightly reduced, falling strength is slightly increased, and drum strength is slightly decreased. Under the conditions of layer height proportion of 320/400 $\mathrm{mm}$ (lower/upper) and ignition time interval of $10 \mathrm{~min}$, the yield, drum strength, shatter strength, and solid fuel consumption were reached $61.60 \%, 54.82 \%, 46.75 \%$, and $69.55 \%$, respectively.

(3) In contrast to the single-layer sintering, $\mathrm{NO}_{x}$ concentration under the $16 \%$ baseline oxygen content $\left(\mathrm{c}\left(\mathrm{NO}_{\mathrm{x}}\right)\right)$ in the flue gas of double-layer ignition sintering is reduced. The $\mathrm{CO}_{2}$ concentration in flue gas of double-layer ignition sintering was higher, and the $\mathrm{O}_{2}$ concentration was lower. The oxidizing atmosphere in the upper sintering flue gas is weakened, and the high-temperature hot sintered ore in the lower layer provides favorable conditions for catalytic reduction of $\mathrm{NO}_{\mathrm{x}}$. 
The double-layer ignition sintering can reduce $\mathrm{NO}_{\mathrm{x}}$ emission in sintering process under the condition of guaranteeing the sintering index, which provides a way to reduce $\mathrm{NO}_{\mathrm{x}}$ emission in the sintering process.

Author Contributions: Conceptualization, T.C. and X.Z.; methodology, J.W. and Y.L.; software, J.W.; validation, T.C., X.Z. and B.S.; formal analysis, Z.W.; resources, T.C.; data curation, J.W., J.L. and M.H.; writing-original draft preparation, J.W.; writing-review and editing, T.C., X.Z. and Y.L.; project administration, X.Z.; funding acquisition, B.S. and Z.W. All authors have read and agreed to the published version of the manuscript.

Funding: This research was funded by [the Basic Research Fund of Zhongye Changtian International Engineering Co., Ltd.] grant number [No. 2020JCYJ06], the APC was funded by [Wuhan University of Science and Technology].

Data Availability Statement: Not applicable.

Conflicts of Interest: The authors declare no conflict of interest.

\section{References}

1. Rocha, L.; Kim, H.; Lee, C.; Jung, S.M. Mechanism of $\mathrm{NO}_{\mathrm{x}}$ Formation from Nitrogen in the Combustion of the Coals Used in Sintering Process. Metall. Mater. Trans. B 2020, 51, 2068-2078. [CrossRef]

2. Chen, Y.G.; Guo, Z.C.; Wang, Z. Influence of $\mathrm{CeO}_{2}$ on $\mathrm{NO}_{\mathrm{x}}$ emission during iron ore sintering. Fuel Processing Technol. 2009, 90, 933-938. [CrossRef]

3. Lu, P.; Hao, J.T.; Yu, W.; Zhu, X.M.; Dai, X. Effects of water vapor and Na/K additives on NO reduction through advanced biomass reburning. Fuel 2015, 170, 60-66. [CrossRef]

4. $\quad$ Fan, X.H.; Yu, Z.Y.; Gan, M.K.H.; Chen, X.L.; Chen, Q.; Liu, S.; Huang, Y.S. Elimination Behaviors of $\mathrm{NO}_{\mathrm{x}}$ in the Sintering Process with Flue Gas Recirculation. ISIJ Int. 2015, 55, 2074-2081. [CrossRef]

5. Liu, D.J.; Wei, Y.Q.; Yang, L.Q. Research of emission reduction of nitrogen oxide in Chinese iron and steel enterprises. Environ. Eng. 2012, 5, 118-123.

6. Zhu, T.Y. Sintering Flue Gas Purification Technology; Chemical Industry Press: Beijing, China, 2009.

7. Ni, W.J.; Li, H.F.; Zhang, Y.Y.; Zou, Z.S. Effects of Fuel Type and Operation Parameters on Combustion and $\mathrm{NO}_{\mathrm{x}}$ Emission of the Iron Ore Sintering Process. Energies 2019, 12, 213. [CrossRef]

8. Speth, K.; Murer, M.; Spliethoff, H. Experimental Investigation of Nitrogen Species Distribution in Wood Combustion and Their Influence on NOx Reduction by Combining Air Staging and Ammonia Injection. Energy Fuels 2016, 30, 5816-5824. [CrossRef]

9. Xu, M.X.; Li, S.Y.; Wu, Y.H.; Jia, L.S.; Lu, Q.G. Effects of $\mathrm{CO}_{2}$ on the fuel nitrogen conversion during coal rapid pyrolysis. Fuel 2016, 184, 430-439. [CrossRef]

10. Gan, M.; Fan, X.H.; Lv, W.; Chen, X.L.; Yu, Z.Y.; Zhou, Y. Fuel pre-granulation for reducing $\mathrm{NO}_{\mathrm{x}}$ emissions from the iron ore sintering process. Powder Technol. 2016, 301, 478-485. [CrossRef]

11. Wo, C.N. NOx Formation of Pulverized Coal under Pressure Oxygen-Enriched Combustion. Master's Thesis, Zhejiang University, Hangzhou, China, 2020.

12. Gan, M.; Fan, X.; Ji, Z.; Jiang, T.; Chen, X.; Yu, Z.; Li, G.; Yin, L. Application of biomass fuel in iron ore sintering: Influencing mechanism and emission reduction. Ironmak. Steelmak. Processes Prod. Appl. 2014, 42, 27-33. [CrossRef]

13. Mo, C.L.; Teo, C.S.; Hamilton, I.; Morrison, J. Admixing Hydrocarbons in Raw Mix to Reduce $\mathrm{NO}_{\mathrm{x}}$ Emission in Iron Ore Sintering Process. ISIJ Int. 1997, 37, 350-357. [CrossRef]

14. Chen, Y.G.; Guo, Z.C.; Wang, Z. Application of Modified Coke to $\mathrm{NO}_{\mathrm{x}}$ Reduction with Recycling Flue Gas during Iron Ore Sintering Process. ISIJ Int. 2008, 11, 1517-1523. [CrossRef]

15. Cheng, Z.L.; Wang, J.Y.; Wei, S.S.; Guo, Z.G.; Yang, J.; Wang, Q.W. Optimization of gaseous fuel injection for saving energy consumption and improving imbalance of heat distribution in iron ore sintering. Appl. Energy 2017, 207, 230-242. [CrossRef]

16. Yu, Z.Y.; Fan, X.H.; Gan, M.; Chen, X.L.; Lv, W. NO $\mathrm{N}_{\mathrm{x}}$ Reduction in the Iron Ore Sintering Process with Flue Gas Recirculation. JOM 2017, 69, 1570-1574. [CrossRef]

17. Locci, C.; Vervisch, L.; Farcy, B.; Domingo, P.; Perret, N. Selective Non-Catalytic Reduction (SNCR) of Nitrogen Oxide Emissions: A Perspective from Numerical Modeling. Flow Turbul. Combust. 2018, 100, 301-340. [CrossRef]

18. Mahmoudi, S.; Baeyens, J.; Seville, J. NOx formation and selective non-catalytic reduction (SNCR) in a fluidized bed combustor of biomass. Biomass Bioenergy 2010, 34, 1393-1409. [CrossRef]

19. Procházka, L.; Mec, P. Possibility of using fly ash after denitrification by SNCR as admixture in alkali-activated materials. Mater. Today Proc. 2020, 37, 42-47. [CrossRef]

20. Chen, X.P.; Liu, Q.; Wu, Q.; Luo, Z.K.; Zhao, W.T.; Chen, J.J.; Li, J.H. A hollow structure $\mathrm{WO}_{3} @ \mathrm{CeO}_{2}$ catalyst for $\mathrm{NH}_{3}-\mathrm{SCR}$ of $\mathrm{NOx}$ Catal. Commun. 2021, 149, 106252. [CrossRef]

21. Jiang, B.Q.; Zhao, S.; Wang, Y.L.; Wenren, Y.S.; Zhang, X.M. Plasma-enhanced low temperature $\mathrm{NH}_{3}-\mathrm{SCR}_{\text {of }} \mathrm{NO}_{\mathbf{x}}$ over a $\mathrm{Cu}-\mathrm{Mn} / \mathrm{SAPO}-34$ catalyst under oxygen-rich conditions. Appl. Catal. B Environ. 2021, 286, 119886. [CrossRef] 
22. Xu, G.Y.; Guo, X.L.; Cheng, X.X.; Yu, J.; Fang, B.Z. A review of Mn-based catalysts for low-temperature $\mathrm{NH}_{3}-\mathrm{SCR}^{\mathrm{N}} \mathrm{NO}_{\mathrm{x}}$ removal and $\mathrm{H}_{2} \mathrm{O} / \mathrm{SO}_{2}$ resistance. Nanoscale 2021, 13, 7052-7080. [CrossRef] [PubMed]

23. Carlos, L.; Moreno-Pirajan, J.C. Adsorption microcalorimetry Characterisation of activated carbons and their application in the study of $\mathrm{NO}_{\mathrm{x}}$ retention. J. Therm. Anal. Calorim. 2015, 121, 245-255.

24. Song, Z.J.; Wang, B.; Yang, W.; Chen, T.; Sun, L. Research on $\mathrm{NO}$ and $\mathrm{SO}_{2}$ removal using $\mathrm{TiO}_{2}$ supported iron catalyst with vaporized $\mathrm{H} 2 \mathrm{O} 2$ in a catalytic oxidation combined with absorption process. Environ. Sci. Pollut. R 2020, 27, 18329-18344. [CrossRef] [PubMed]

25. Sahin, Z.; Tuti, M.; Durgun, O. Experimental investigation of the effects of water adding to the intake air on the engine performance and exhaust emissions in a DI automotive diesel engine. Fuel 2014, 115, 884-895. [CrossRef]

26. Xiao-Hui, J.I. Influence of $\mathrm{O}_{2}$ Content in Circulating Flue Gas on Iron Ore Sintering. J. Iron Steel Res. Int. 2013, $20,1-6$.

27. Menad, N.; Tayibi, H.; Carcedo, F.G.; Hernandez, A. Minimization methods for emissions generated from sinter strands: A review. J. Clean. Prod. 2006, 14, 740-747. [CrossRef]

28. Fleischander, A.; Aichinger, C.; Zwittag, E. New developments for achieving environmentally friendly sinter production-Eposint and MEROS. China Metall. 2008, 18, 41-46.

29. Sidorkin, V.T.; Tugov, A.N.; Moshnikov, A.N.; Vereshchetin, V.A.; Bersenev, K.G. Effect of Flue Gas Recirculation on the Technical and Environmental Performance of a Boiler. Power Technol. Eng. 2016, 49, 354-358. [CrossRef]

30. Vanderheyden, B.; Borlee, J.; Brouhon, M. Impact of Waste Gas Recycling on Sintering Performances and Emissions; U.S. Department of Energy, Office of Scientific and Technical Information: Pittsburgh, PA, USA, 1996; Volume 55, p. 807.

31. Schmid, H.; Zwittag, E.; Reidetschlager, J.; Kainz, K.; Guan, Y. Eposint-A New Waste—Gas Recycling System for Sinter Plants World Iron Steel 2007, 3, 6-9.

32. Pourhoseini, S.H.; Taghvaei, I.; Moghiman, M.; Baghban, M. Tangential Flue Gas Recirculation (TFGR) technique for enhancement of radiation characteristics and reduction of $\mathrm{NO}_{x}$ emission in natural gas burners. J. Nat. Gas Sci. Eng. 2021, 94, 104130. [CrossRef]

33. Pan, J. Research on Basic Theory and Technology of Reduction Emission of Sintering Flue Gas in Iron Ore. Ph.D. Thesis, Central South University, Changsha, China, 2007.

34. Zhong, Q.; Liu, H.B.; Xu, L.P.; Zhang, X.; Rao, M.J.; Peng, Z.W.; Li, G.H.; Jiang, T. An efficient method for iron ore sintering with high-bed layer: Double-layer sintering. J. Iron Steel Res. Int. 2021, 28, 1366-1374. [CrossRef]

35. Yu, Z.Y.; Fan, X.H.; Gan, M.; Chen, X.L. Effect of Ca-Fe oxides additives on $\mathrm{NO}_{\mathrm{x}}$ reduction in iron ore sintering. J. Iron Steel Res. Int. 2017, 24, 18-23. [CrossRef]

36. Yunas, J.; Sulaiman, N.H.; Ghazali, M.J. Comparative Study of the Calcium Ferrite Nanoparticles $\left(\mathrm{CaFe}_{2} \mathrm{O}_{4}\right.$-NPs) Synthesis Process. In Proceedings of the 2018 IEEE International Conference on Semiconductor Electronics (ICSE), Kuala Lumpur, Malaysia, 15-17 August 2018; pp. 101-103.

37. Wang, X.; Liu, Y.; Han, H.; Zhao, Y.; Ma, W.; Sun, H. Polyaniline coated $\mathrm{Fe}_{3} \mathrm{O}_{4}$ hollow nanospheres as anode materials for lithium ion batteries. Sustain. Energy Fuels 2017, 1, 915-922. [CrossRef]

38. Jiang, S.Y.; Zhou, R.X. Ce doping effect on performance of the Fe/b catalyst for NOx reduction by $\mathrm{NH}_{3}$. UEL Processing Technol. 2015, 133, 220-226. [CrossRef]

39. Frank, B.; Renken, A. Kinetics and deactivation of the NO reduction by CO on Pt-supported catalysts. Chem. Eng. Technol. 1999, 22, 490-494. [CrossRef]

40. Gan, M.; Fan, X.H.; Yu, Z.Y.; Chen, X.L.; Ji, Z.Y.; Lv, W.; Liu, S.; Huang, Y.-S. A laboratory-based investigation into the catalytic reduction of NOx in iron ore sintering with flue gas recirculation. Ironmak. Steelmak. 2016, 43, 441-449. [CrossRef]

41. Ge, X.; Chen, J.Q.; Zhang, H.L. Preparation, characterization and catalytic activity of the spinel ferrites. Chin. J. Inorg. Chem. 1999, $15,730-731$.

42. Fan, X.H.; Yu, Z.Y.; Gan, M.; Chen, X.-L.; Ji, Z.Y. Combustion behavior and influence mechanism of CO on iron ore sintering with flue gas recirculation. J. Cent. South Univ. 2014, 21, 2391-2396. [CrossRef]

43. Wu, S.L.; Chen, D.F.; Zhao, C.X.; Zhang, L.H.; Xue, F. Influence of Bed Depth on Sinter Flue Gas Composition and Emission. In Proceedings of the 5th International Congress on the Science and Technology of Ironmaking, Shanghai, China, 20-22 October 2009; pp. 519-523.

44. Liu, F.Q.; Wang, S.L.; Gu, A.J. Analysis of influence factors of sinter strength and grain size composition. Ironmak. Technol. Newwsl. 2009, 4, 27-29.

45. Jiang, D.J. Influence of fuel structure on sintering character and comprehensive effect. Iron Steel 2020, 55, 31-41.

46. Xu, B.; Zhuang, J.M.; Bai, G.H.; Liang, J.S. On Improving the Particle Size of Sinter. Sinter. Pelletizing 2001, 26, $19-21$.

47. Qian, F.; Chyang, C.S.; Chiou, J.B.; Tso, J. Effect of Flue Gas Recirculation (FGR) on $\mathrm{NO}_{\mathrm{x}}$ Emission in a Pilot-Scale Vortexing Fluidized-Bed Combustor. Energy Fuels 2011, 25, 5639-5646. [CrossRef]

48. Zhou, H.; Zhou, M.X.; Liu, Z.H.; Cheng, M.; Chen, J.Z. Modeling NOx emission of coke combustion in iron ore sintering process and its experimental validation. Fuel 2016, 179, 322-331. [CrossRef]

49. Xu, C.B.; Wu, S.L.; Cang, D.Q.; GeXi, R.F. Catalytical performance of several metallic oxides on elimination of NO in NO-CO$\mathrm{CO}_{2}-\mathrm{N}_{2}$ system. Chin. Environ. Sci. 1998, 18, 1-6.

50. Okazakf, K.; Ando, T. $\mathrm{NO}_{\mathrm{x}}$ reduction mechanism in coal combustion with recycled $\mathrm{CO}_{2}$. Energy 1997, 22, 207-215. [CrossRef] 